\title{
Native Plant Growth and Seedling Establishment in Soils Influenced by Bromus tectorum
}

\author{
Helen I. Rowe $e^{1}$ and Cynthia S. Brown ${ }^{2}$ \\ Authors are ${ }^{1}$ Research Professor, Forestry and Natural Resources Department, Purdue University, 195 Marsteller Street, West Lafayette, IN 47907, USA; and \\ ${ }^{2}$ Assistant Professor, Department of Bioagricultural Sciences and Pest Management, 1177 Campus Delivery, Colorado State University, Fort Collins, CO 80523, USA.
}

\begin{abstract}
The invasion of 40 million hectares of the American West by cheatgrass (Bromus tectorum L.) has caused widespread modifications in the vegetation of semi-arid ecosystems and increased the frequency of fires. In addition to well-understood mechanisms by which cheatgrass gains competitive advantage, it has been implicated in reducing arbuscular mycorrhizal fungi (AMF) abundance and taxa diversity. We evaluated this possibility at a high elevation site in a two-pronged approach. To test whether cheatgrass changed native AMF communities in ways that affected subsequent native plant growth, we grew cheatgrass and native plants in native soils and then planted native plants into these soils in a greenhouse experiment. We found that cheatgrass-influenced soils did not inhibit native plant growth or AMF sporulation or colonization. To test whether soils in cheatgrass-dominated areas inhibited establishment and growth of native plants, cheatgrass was removed and six seeding combinations were applied. We found that $14.02 \pm 1.7$ seedlings $\cdot \mathrm{m}^{-2}$ established and perennial native plant cover increased fourfold over the three years of this study. Glyphosate reduced cheatgrass cover to less than $5 \%$ in the year it was applied but did not facilitate native plant establishment or growth compared with no glyphosate. We conclude that cheatgrass influence on the soil community does not appear to contribute to its invasion success in these high elevation soils. It appears that once cheatgrass is controlled on sites with sufficient native plant abundance, there may be few lingering effects to inhibit the natural reestablishment of native plant communities.
\end{abstract}

\section{Resumen}

La invasión de 40 millones de hectáreas del Oeste Americano por espiguilla colgante (Bromus tectorum L.) ha causado modificaciones generalizadas en la vegetación de ecosistemas semiáridos y ha incrementado la frecuencia de los fuegos. Además de los mecanismos bien comprendidos por los cuales la espiguilla colgante tiene una ventaja competitiva, también tiene influencia en la reducción de la abundancia del hongo micorrizo arbuscular (AMF) y la diversidad de taxones. Se evaluó esta posibilidad en un sitio de elevación alta en un enfoque de dos puntas. Para probar si la espiguilla colgante cambio las comunidades nativas de AMF de maneras que afecten subsecuente el crecimiento de la planta nativa, se cultivó espiguilla colgante y plantas nativas en suelos nativos, y luego sembramos plantas nativas en estos suelos en un experimento de invernadero. Nosotros encontramos los suelos influenciados por la espiguilla colgante no inhibió el crecimiento de la planta nativa o la esporulación de AMF o la colonización. Para estudiar si los suelos dominados por la espiguilla colgante inhiben el establecimiento y crecimiento de plantas nativas, La espiguilla colgante fue removida y seis combinaciones de sembrado fueron aplicadas. Nosotros encontramos que $14.02 \pm 1.7$ juveniles $\cdot \mathrm{m}^{-2}$ establecidos y la cobertura de plantas perennes aumentó cuatro veces durante los 3 años de este estudio. El glifosato redujo la cobertura de la espiguilla colgante a menos del $5 \%$ en el año que este fue aplicado, pero no facilito el establecimiento o el crecimiento de la plantas nativas comparado a los tratamientos sin glifosato. Nosotros concluimos que la influencia de la espiguilla colgante sobre la comunidad del suelo no parece contribuir a su éxito invasivo en eso suelos de elevación alta. Parece que una vez que la espiguilla colgante es controlada en sitios con suficiente abundancia de plantas nativas, puede haber algunos efectos persistentes para inhibir el reestablecimiento natural de las comunidades de plantas nativas.

Key Words: arbuscular mycorrhizal fungi, cheatgrass, invasions, native species, Rocky Mountain National Park

\section{INTRODUCTION}

Approximately $20 \%$ of the sagebrush-steppe vegetation zone in the western United States is dominated by cheatgrass to the point where the establishment of native perennial species is nearly impossible (Knapp 1996). It is estimated that cheatgrass and other rangeland weeds together result in economic losses of

Research was funded by the Dept of the Interior Cooperative Conservation Initiative, Rocky Mountain National Park, and the Center for Invasive Plant Management, Bozeman, MT, USA.

Correspondence: Helen Ivy Rowe, Center for the Environment, Purdue University, 503 Northwestern Ave, West Lafayette, IN 47907, USA. Email: ivy@purdue.edu

Manuscript received 9 January 2008; manuscript accepted 19 August 2008.
$\$ 2$ billion annually in the United States (DiTomaso 2000). The success of cheatgrass (downy brome; Bromus tectorum L.) as an invading species has been largely attributed to its winter annual life history (Hulbert 1955), competitive advantage in disturbed, high-nutrient environments (Kay and Evans 1965; Dakheel et al. 1993), and the accumulation of fine fuels early in the growing season that contribute to increased fire frequency. All of these factors reduce native species abundance and increase cheatgrass dominance (Klemmedson 1964; Humphrey and Schupp 2001).

Interactions between the invasive grass cheatgrass and arbuscular mycorrhizal fungi (AMF) may also contribute to its invasion success (Goodwin 1992). AMF typically form 
mutual relationships with a wide range of plant species and provide nutrients and plant protection from herbivory and parasites and improve water relations in exchange for photosynthates (Smith and Read 1997). Many perennial species are dependent on mycorrhizal symbiosis for optimal nutrient uptake and growth; therefore soil depleted of these mutualists may inhibit growth and natural regeneration of perennial species (Allen 1988, 1995; Smith and Read 1997). In contrast, cheatgrass has been shown to have a negative to neutral growth response with AMF colonization (Allen 1988; Wilson and Hartnett 1998; Rowe et al. 2007). Invasion of cheatgrass into native grasslands has corresponded with changes in AMF composition, a reduction in viable AMF propagules, and lower AMF richness in native grasses (Al-Qarawi 2002; Hawkes et al. 2006), altered soil food web structure, and influenced a shift from mutualistic soil fungal composition to more parasitic and saprophytic forms (Belnap and Philips 2001).

Plant species have a unique relationship with AMF such that AMF taxon composition changes according to the host plant species (Bever et al. 1996). Because of this relationship, the introduction of novel plants to a community has the potential to change AMF composition (for a review see Wolfe and Klironomos 2005). The new community can result in either positive feedbacks, in which the AMF that benefits most from the plant returns benefits back to that plant, or negative feedbacks, in which the AMF that benefit most from the plant provide more benefits to other plant species. The former case leads to monocultures, whereas the latter results in increased plant community diversity (Bever 2002; Bever et al. 2002). These feedbacks can be tested, as we did here, by using plants to "train" soils (influence the AMF community structure), then planting indicator plants in those soils to show whether the soil training has positive or negative feedbacks (Bever et al. 2002).

In the past two decades, managers have observed cheatgrass spread into higher elevations where fire cycles have not been disrupted. These environments offer an opportunity to study the effects of altered soil communities as a mechanism of invasion in isolation from fire effects. In two experiments we sought to address the following restoration management question: does cheatgrass have direct effects on the AMF community that contribute to its dominance in a positive feedback loop? To answer this question, first, we conducted a greenhouse study to test whether cheatgrass benefits from positive AMF feedbacks relative to native plants. We investigated this question in the field by removing cheatgrass from plots and seeding with different combinations of species to evaluate whether soil conditions, in the absence of cheatgrass competition, were sufficient for seedling establishment. Productivity of existing vegetation was also measured to test whether conditions were suitable for native plant growth.

\section{METHODS}

\section{Greenhouse Soil Training Experiment}

Experimental Design. In "training" experiments, AMF community structure is not measured directly but through plant response. In a greenhouse experiment we tested whether cheatgrass had positive feedbacks with AMF that would compromise revegetation efforts. In the case of a positive feedback, both cheatgrass and associated AMF would benefit, leading to increased cheatgrass dominance (sensu Bever 2002). We sampled indicator plant growth, percentage AMF root colonization, and number of spores. The greenhouse experiment was a $2 \times 2 \times 4$ complete randomized design with two inoculum sources/indicator plants $\times$ two levels of AMF (no AMF and AMF: autoclaved soil with filtrate and nonautoclaved soil, respectively), four trainer plant species, and four replicates of each treatment combination. The four trainer plants were fringed sage (Artemisia frigida Willd.), Chrysothamnus viscidiflorus, cheatgrass, and Elymus elymoides (Raf.) Swezey. Elymus elymoides was chosen as a trainer species because of its similarity to cheatgrass in life history, family (Poaceae), and response to AMF. Elymus elymoides is a short-lived perennial with a negative mycorrhizal responsiveness similar to cheatgrass (Rowe et al. 2007) but is native to the western United States. Directly after trainer plants were removed, Artemisia frigida and C. viscidiflorus were seeded into pots as bioindicators of soil training effects. These species were chosen as "indicator" and "trainer" species because their high mycorrhizal responsiveness to native soil inoculum (Rowe et al. 2007) may make them sensitive to soil training.

Seeds for each species were collected near the field site in Rocky Mountain National Park (RMNP) at approximately $2438 \mathrm{~m}$ (8000 feet). Two sources of aggregate soil inocula were collected (hereafter inoculum), one from the root zones of A. frigida plants and one from the root zones of C. viscidiflorus plants in RMNP. Because of National Park regulations, sufficient soil inocula could not be collected to fill the pots. Instead, RMNP provided topsoil for use as potting soil; this soil was collected and stockpiled within $3 \mathrm{~km}$ of the inocula collection site. Because the stockpiled soil had twice the level of phosphorus (43 ppm P, Weak Bray; A \& L Western Agricultural Labs, Modesto, CA) as other field soil at RMNP (21.7 ppm P, Weak Bray), we diluted the topsoil with coarse sand at a 1:1 ratio and autoclaved all of the potting soil.

Half of each of the inoculum to be used for controls was autoclaved and incubated with soil microbial filtrate. The filtrate was prepared by passing a mixture of $2.2 \mathrm{~L}$ of nonautoclaved control inoculum soil and $9 \mathrm{~L}$ of deionized water through Whatman no. 1 filter paper to remove AMF (Gemma et al. 2002). The filtrate reintroduced bacteria, saprobes, and parasitic fungi to the controls so that the only difference between the control and treatment soils was the microbial fraction larger than $12 \mu \mathrm{m}$. Choosing a pore size is a trade-off between excluding AMF from the control and ensuring that non-AMF (saprophytes and parasites) are reintroduced.

Sixty-four pots were filled with $1.55 \mathrm{~L}$ of potting soil and $50 \mathrm{~mL}$ of one of the four inoculum soils (A. frigida, autoclaved A. frigida, C. viscidiflorus, autoclaved C. viscidiflorus) in the center column. Trainer plants were seeded into these pots and watered twice daily with drip irrigation for $10 \mathrm{~d}$, once daily to field capacity for a further $14 \mathrm{~d}$, and then three times weekly for $5 \mathrm{~min}$ allowing the soil to dry between watering. At $74 \mathrm{~d}$ and $81 \mathrm{~d}$ soil surfaces of all pots were scraped to kill off moss or algae growth. From the 25 th day after planting, plants were also watered with ammonium nitrate $\left(0.0145 \mathrm{~g} \cdot \mathrm{L}^{-1}\right)$ and potassium nitrate $\left(0.04 \mathrm{~g} \cdot \mathrm{L}^{-1}\right)$ fertilizer each week. We moved 
pots to different locations on the bench weekly using a randomized design with precautions taken to sterilize irrigation emitters before replacing them in pots.

After $151 \mathrm{~d}$ the trainer plants were cut at the soil level and removed. At this time a single $2.5-\mathrm{cm}$ diameter core sample $(50 \mathrm{~mL}$ soil) was taken from each pot directly adjacent to the plant shoot. Trainer plant roots were removed from the core sample for AMF assessment, and the remaining soil was stored at $-2^{\circ} \mathrm{C}$. The core hole was filled with sterilized sand, and the two indicator species were seeded into pots containing their respective original inocula. We seeded directly into existing pots rather than transferring inocula into new pots to retain as many existing AMF reproductive structures as possible, including the external hyphal mycelium, roots, and spores. Indicator plants were watered twice daily for $31 \mathrm{~d}$, then three times a week thereafter, fertilized as described above starting in the fourth week, and harvested at $13 \mathrm{wk}$.

AMF Analysis. Roots of trainer and indicator plants were fixed in a $50 \%$ alcohol solution, cleared in $4 \% \mathrm{KOH}$ solution for $15 \mathrm{~min}$, acidified in $1 \% \mathrm{HCl}$ solution overnight, stained in hot $5 \%$ Shaeffer black ink $/ 95 \%$ vinegar solution for $3 \mathrm{~min}$, and then destained using a 16:1:1 lactic acid:glycerol:water solution (Kormanik et al. 1980; Koske and Gemma 1989; Vierheilig et al. 1998). We verified presence/absence of AMF colonization for each trainer plant with light microscopy at $\times 100-400$ magnification. Percentages of indicator plant roots colonized by hyphae, vesicles, arbuscules, and non-AMF structures were assessed by viewing 100 intersections per sample using the magnified intersection method (McGonigle et al. 1990). This method allows for analysis of relative AMF function (Johnson et al. 2003); however, for simplicity, because the additional data concerning structures do not provide additional information beyond that of overall percentage colonization, only overall percentage colonization is presented here. All inoculated target and indicator plant root samples were colonized, whereas none of the control samples were colonized by AMF. The efficacy of the microbial wash for reintroducing a nonmycorrhizal microbial community into the controls was confirmed; no difference in the presence of non-AMF structures was found between the AMF and the non-AMF treatments (AMF treatments: $6.0 \pm 1.8 \%$; non-AMF treatments: $4.4 \pm 1.5 \%, P=0.46)$. The roots that had structures other than those of AMF were examined further for presence of other fungi. Trace amounts of non-AMF were observed in only three indicator plant samples. These samples were not associated with lower biomass than uninfected samples of the same treatment; thus parasitic fungi were unlikely to have interfered with treatment effects.

Spores were extracted from $50 \mathrm{~mL}$ of each thawed soil core sample using the wet sieve and sucrose gradient method (Daniels and Skipper 1982). Spores were counted based on low-density direct counts (International Culture Collection of [Vesicular] Arbuscular Mycorrhizal Fungi 2005). Larger spores were separated with a $250 \mu \mathrm{m}$ sieve and viewed at $\times 7$ magnification. All spores were removed and placed on slides with 50:50 polyvinyl lacto-glycerol:Meltzer's solution. Only spores that released lipids when they were crushed with a cover slip indicating viability were included in the final count $(\mathrm{J}$. Bever, Indiana University, Bloomington, personal communica- tion, October 2005). The remaining smaller spore suspension was diluted to $25 \mathrm{~mL}$, vortexed, and $1 \mathrm{~mL}$ was transferred to each of four watch glasses. Watch glasses were viewed at $\times 40$ magnification. Smaller spores were removed and counted in the same manner as the larger spores. The total spore count per sample was calculated as the large spore count plus the average number of small spores per watch glass, multiplied by volume of the initial solution $(25 \mathrm{~mL})$. Because spores are primarily reproductive bodies, spore counts can be used as a proxy to measure population growth (Bever 2002).

Plant Biomass. Indicator plant roots were carefully separated from the trainer roots, but inextricable trainer roots remained in the indicator roots. Shoots and roots were dried to constant mass at $55-60^{\circ} \mathrm{C}$ and weighed. Indicator shoot biomass correlated well with the indicator root biomass $\left(R^{2}=0.67\right.$, $P<0.0001$ ), and inclusion of the root data within analysis of indicator biomass did not alter the trends of the shoot data. However, because the root biomass could not be cleanly separated, only shoot biomass data are presented.

Statistical Analysis. Variances and outliers were analyzed using Studentized residual plots. Spore counts and indicator shoot biomass were square root transformed. Above-ground indicator plant biomass within indicator species was analyzed using a $t$ test to evaluate differences between colonized and uncolonized plants in the respective treatments. Above-ground indicator plant biomass, spore counts from after the soil training, and percentage hyphae, arbuscules, and vesicles of the indicator plants were analyzed in a two-way analysis of variance (ANOVA; SAS Institute 2002-2003) with inocula/ indicator and trainer plant as the independent variables. Differences in treatment means were compared using Tukey's HSD test. Pearson correlation coefficients were used to compare correlations between appropriate data.

\section{Field Experiment}

Site Description. The experimental plots were located between $2377 \mathrm{~m}$ and $2438 \mathrm{~m}$ elevation on a south-facing slope in RMNP. Helianthus pumilus Nutall [low], C. viscidiflorus (Hook.), Purshia tridentata (Pursh) de Candolle, Mublenbergia montana (Nutt.) Hitchc., Hesperostipa comata (Trinius \& Ruprecht) Barkworth, Carex microptera Mack, Boutelona gracilis (Willd. Ex Kunth) Lag. Ex Griffiths, Artemisia ludoviciana Nutt., and Sporobolus cryptandrus Hitchc. comprise much of the natural vegetation with scattered Pinus ponderosa Douglas subsp. scopularum (Watson) Weber. Cheatgrass invasion on this site is patchy, ranging from no cheatgrass in some areas to high dominance $(70-80 \%$ cover) in others. Cheatgrass patches cover areas $5-200 \mathrm{~m}^{2}$ on the study site comprising approximately $4 \times 1 \mathrm{~km}$.

Growing season monthly temperature and precipitation for the duration of the study were similar to the 30 -yr monthly averages (30-yr averages: March $1.4^{\circ} \mathrm{C}, 2.3 \mathrm{~cm}$; April $4.7^{\circ} \mathrm{C}$, $3.6 \mathrm{~cm}$; May $9.2^{\circ} \mathrm{C}, 5.4 \mathrm{~cm}$; June $14.1^{\circ} \mathrm{C}, 3.6 \mathrm{~cm}$; July $17.1^{\circ} \mathrm{C}$, $5.5 \mathrm{~cm}$; August $16.1^{\circ} \mathrm{C}, 5.0 \mathrm{~cm}$; September $12.3^{\circ} \mathrm{C}, 3.1 \mathrm{~cm}$ ) with the following notable exceptions: July 2005 was hotter (deviation from 30-yr average: $+2.2^{\circ} \mathrm{C}$ ), and April, June, and July 2004 were wetter (deviation from 30-yr average: $+4.9 \mathrm{~cm}$, $+8.7 \mathrm{~cm},+8.1 \mathrm{~cm}$, respectively; Western Regional Climate 
Center 2006). However, climate data for the years of this study were not fully comparable to 30 -yr averages because the Estes Park weather station was moved in 2001.

\section{Experimental Design}

One of each of seven treatments was assigned to a $1 \times 1.5 \mathrm{~m}$ plot within each of 12 blocks (84 plots) in a randomized complete block design. We chose to treat and sample a large number of small plots rather than treat a few large plots with multiple subsamples to maximize our statistical power and to evaluate responses across the environmental variability found at the site. Blocking was used to control for environmental gradients and spatial variation in the existing plant community. All treatment plots had cheatgrass cover of $55-70 \%$ and rock cover of less than $10 \%$.

To isolate the soil community effects from cheatgrass competition, cheatgrass was removed to $\leq 5 \%$ cover in April 2004 with glyphosate, applied at a rate of $0.55 \mathrm{~kg} \cdot \mathrm{ha}^{-1}$ with a $\mathrm{CO}_{2}$ pressurized backpack sprayer (Whitson and Koch 1998). Native plants were covered to protect them from spray. Although covering native plants is impractical as a large-scale restoration practice, the same effect may be achieved if spraying occurs in early spring, before native plant emergence.

Treatments included the following 1-yr seeding mixture treatments: late succession species (LS), early and late succession species (ELS), early succession species (ES), nonseeded control (NSC), and a nonglyphosate control seeded as ELS (NGC). Two 2-yr treatments were included: no seed first year, LS second year (LS2), and ES first year, LS second year (ELS2). National Park restrictions precluded a negative control (such as a soil application of fungicide benomyl) to compare with the cheatgrass-invaded soil effects on seedling establishment and native plant growth. Instead we used the greenhouse study to specifically investigate interactions between cheatgrass, AMF, and native plants (see above).

We collected seeds within $2 \mathrm{~km}$ of the field site in the same drainage basin at elevations of approximately $2377-2743 \mathrm{~m}$. Seed was broadcast and rake incorporated by hand following seeding rates of a nearby RMNP restoration project ( 646 filled seeds $\left.\cdot \mathrm{m}^{-2}\right)$. Again, whereas raking by hand may not be practical for large-scale application, some sites may be suitable for mechanical seed incorporation. For species in the LS and ES mixtures, the total seeding density $\left(646 \mathrm{seeds} \cdot \mathrm{m}^{-2}\right)$ was evenly divided among species. The early-late (ELS) treatment received half the seed density of the ES and of LS treatments to equal the same total seed density as the LS and ES treatments. Keeping seeding densities constant in the first-year treatments allowed us to compare overall seeding treatment effects. In the second year both LS2 and ELS2 were seeded with the LS mixture at the same rate (i.e., 646 seeds $\cdot \mathrm{m}^{-2}$ ). Same seeding rates in year two enabled us to compare establishment of late succession species seeded at the same densities in the same year with and without the presence of seeded early succession species.

We characterized late succession seed mix species as perennial and long lived; our late succession mixture included two shrubs (A. frigida and chokecherry [Prunus virginiana $\mathrm{L}]$ ), two forbs (smooth blue aster [Aster laevis L] and E. umbellatum), and two grasses (M. montana and H. comata). Prunus virginiana was grown from seed in the greenhouse and
Table 1. Germination results for seeded species. Percentage viability includes germination and dormancy tests for filled seed.

\begin{tabular}{llc}
\hline & Percentage viability of filled seed & SE \\
\hline Early succession spp. & & \\
Chenopodium leptophyllum & $32^{1}$ & - \\
Elymus elymoides & 92.96 & 0.03 \\
Helianthus pumilus & 35.13 & 0.20 \\
Heterotheca villosa & 83.31 & 0.06 \\
Lappula redowskii & 76.25 & 0.03 \\
Polygonum douglasii & 70.82 & 0.04 \\
Late succession spp. & & \\
Artemisia frigida & 91.68 & 0.02 \\
Aster laevis & 93.68 & 0.01 \\
Chrysothamnus viscidiflorus & 39.59 & 0.03 \\
Eriogonum umbellatum & 90.15 & 0.03 \\
Hesperostipa comata & 74.00 & 0.02 \\
Muhlenbergia montana & 88.63 & 0.03 \\
\hline
\end{tabular}

${ }^{1} \mathrm{C}$. leptophyllum did not germinate in the growth chamber incubation; this result is from $\mathrm{TZ}$ tests taken on one sample. The same batch of seeds germinated well in greenhouse conditions and in the field.

transplanted in the field, but herbivores claimed most of these; thus, this species was omitted from the analyses. Early succession seed mix species were shorter-lived perennials and annuals and included no shrubs, five forbs (flatspine stickseed [Lappula redowskii \{Hornem.\}], H. pumilus, narrowleaf goosefoot [Chenopodium leptophyllum \{Moq.\} Nutt.], Douglas' knotweed [Polygonum douglasii Greene], and hairy false goldenaster [Heterotheca villosa (Pursh\} Shinners]), and one grass (squirreltail [Elymus elymoides \{Raf.\} Swezey]). Germination and dormancy (tetrazolium) tests (Fulbright et al. 1982; Redente et al. 1982; Association of Official Seed Analysts 2003) were conducted on four replicate trays of 50 collected seeds. All species contained viable seed (Table 1).

Monitoring Treatment Effects. Pretreatment baseline estimates of plant cover were taken in August 2003. A single observer visually estimated plant cover and counted individual seedlings by species in a $0.5 \times 1.0 \mathrm{~m}$ quadrat in each plot in July and August 2004 and 2005. The center $0.5 \mathrm{~m}^{2}$ of each plot was surveyed to minimize edge effects. To obtain consistent estimates among plots and plant species, cardboard squares the size of $25 \%, 10 \%, 5 \%$, and $1 \%$ of the measured $0.5 \mathrm{~m}^{2}$ plots were constructed. These squares were used as a guide to estimate the cover of each species on each plot. High correlation between biomass and cover estimates confirmed the efficacy of this technique (Table 2). After the final field measurements in August 2005, annual above-ground primary production was collected, dried at $36^{\circ} \mathrm{C}$ for $72 \mathrm{~h}$, and weighed.

Cover and richness of existing species in the community were analyzed by functional group (cheatgrass, annual forbs, biennial [native and nonnative] forbs, and perennial forbs, perennial grasses, and perennial shrubs; Lauenroth et al. 1978; Paschke et al. 2000). Classification into groups was determined by descriptions on US Department of Agriculture plants database (http://plants.usda.gov/index.html). If a plant species was described as annual and biennial, biennial and perennial, or annual/biennial/perennial, it was categorized as biennial. 
Table 2. Analysis of variance table for percentage cover and species richness analyses, and correlations between biomass and cover estimates. Degrees of freedom columns include numerator degrees of freedom followed by denominator degrees of freedom. Treatments include the six singleyear and multiyear treatments with glyphosate.

\begin{tabular}{|c|c|c|c|c|c|c|c|c|}
\hline \multirow[b]{3}{*}{ Response variable } & \multicolumn{6}{|c|}{ Source of variation ${ }^{1}$} & \multirow{2}{*}{\multicolumn{2}{|c|}{$\begin{array}{l}\text { Correlation of cover } \\
\text { estimates to biomass }\end{array}$}} \\
\hline & \multicolumn{2}{|c|}{ Treatment } & \multicolumn{2}{|c|}{ Time } & \multicolumn{2}{|c|}{ Treatment $\times$ time } & & \\
\hline & $d f$ & $F$ value & $\mathrm{df}$ & $F$ value & $d f$ & $F$ value & $R$ & $P$ \\
\hline \multicolumn{9}{|l|}{ Cover } \\
\hline B. tectorum & 6,66 & 21.93 & 4, 296 & $398.7^{\star \star \star}$ & 24,296 & 13.84 & 0.72 & $<0.0001$ \\
\hline Annual forbs & 6,66 & 1.44 & 4,297 & $42.79^{\star * *}$ & 24,297 & 1.10 & 0.73 & $<0.0001$ \\
\hline \multicolumn{9}{|l|}{ Biennial forbs } \\
\hline Native & 6,66 & 0.78 & 4,297 & 1.93 & 24, 297 & 0.80 & $* * * *$ & $\star * * *$ \\
\hline Nonnative & 6,66 & 1.87 & 4,297 & $4.18^{\star \star}$ & 24,297 & 1.10 & 0.95 & $<0.0001$ \\
\hline Perennial grasses & 6,66 & 0.22 & 4, 297 & $66.45^{\star \star *}$ & 24, 297 & 1.20 & 0.80 & $<0.0001$ \\
\hline Perennial forbs & 6,66 & $2.12^{2}$ & 4,297 & $32.71^{\star \star *}$ & 24, 297 & 0.62 & 0.89 & $<0.0001$ \\
\hline Perennial shrubs & 6,66 & 0.50 & 4,297 & $10.88^{\star * *}$ & 24,297 & 0.89 & 0.95 & $<0.0001$ \\
\hline \multicolumn{9}{|l|}{ Richness } \\
\hline Annual forbs & 6,66 & 0.81 & 4,297 & $35.19^{\star \star *}$ & 24,297 & 0.69 & & \\
\hline \multicolumn{9}{|l|}{ Biennial forbs } \\
\hline Nonnative & 6,66 & 2.11 & 4,297 & $3.32^{\star \star}$ & 24, 297 & 1.17 & & \\
\hline Perennial grasses & 6,66 & 0.63 & 4,297 & $39.58^{\star \star *}$ & 24, 297 & $2.14^{\star \star}$ & & \\
\hline Perennial forbs & 6,66 & $2.95^{\star, 2}$ & 4,297 & $22.71^{\star * *}$ & 24, 297 & 0.9 & & \\
\hline Perennial shrubs & 6,66 & 0.52 & 4,297 & $9.32^{\star \star \star}$ & 24,297 & 0.8 & & \\
\hline
\end{tabular}

${ }^{1}$ Significance levels: ${ }^{*}$ at $\alpha=0.05 ;{ }^{* *}$ at $\alpha=0.01 ;{ }^{* *}$ at $\alpha=0.001 ;{ }^{* \star * *}$ due to missing data, this correlation could not be calculated

${ }^{2}$ Significant differences in perennial forb cover and richness predated treatment applications.

Statistical Analysis. Studentized residual plots were used to evaluate the distributional properties of the data. We transformed the data to best meet assumptions of normality and homogeneity of variance and to minimize outlier effects. Cover estimate and number of seedling data were rank transformed. Richness data were arcsine square root transformed. Cheatgrass cover data did not require transformation.

We analyzed the early succession and late succession seedling establishment separately with treatment as a fixed effect and block as a random effect using Procedure Mixed (SAS 20022003). Analysis of early succession seedling establishment included all glyphosate treatments, because early succession species were all seeded in the same year. We compared the establishment of late succession species separately for the 1-yr and 2-yr glyphosate treatments because, at the last sampling date, the late succession species had only $1 \mathrm{yr}$ to establish in the 2-yr treatments (LS2, ELS2), whereas the 1-yr treatments (ELS, LS) had $2 \mathrm{yr}$ to establish. The 1-yr and 2-yr treatments were both compared to the no seed control treatment (NSC). The nonglyphosate treatment (NGC) was not included in these analyses because it differs in both seeding and glyphosate treatment factors. F-protected differences of least squared means were used to separate means with $\alpha=0.05$. Because $A$. laevis seedlings and $P$. virginiana transplants were found in fewer than three plots each, they were excluded from analyses.

A repeated measures design with glyphosate seed treatments as fixed effects and block as a random effect was used to evaluate cheatgrass, annual forb (total, native, and nonnative), biennial forb (total, native, and nonnative), perennial grass, forb, and shrub cover and richness differences among treatment plots over time using Procedure Mixed (SAS 2002-2003). Again the nonglyphosate treatment (NGC) was not included in these analyses because it differs both in seeding and glyphosate treatment factors. Autoregressive, lag error structure was used with the repeated measures to account for higher correlation between time points closer together than those farther apart. Data were not analyzed for native biennial richness treatment differences because there was only one species in this category.

Pretreatment cover estimate comparisons showed that differences among treatment plots were present before treatment application for perennial forb cover and species richness, but for no other functional groups (ANOVA; SAS 2002-2003). The 1-yr and 2-yr treatments were analyzed separately and together. The only difference between the two approaches occurred with biennial forb cover and richness. When the 1-yr and 2-yr treatments were analyzed separately, there were no differences, but when comparing all samples together, differences between the 1-yr and 2-yr treatments were detected. For simplicity, we present the combined analysis. Biomass data were highly correlated with cover estimated immediately before cutting (August 2005), which supports using the three seasons of cover data to estimate changes in biomass production over time (Table 2).

To compare effects of cheatgrass removal with glyphosate we compared the two 1-yr treatments with ELS treatments with and without glyphosate control (ELS and NGC, respectively) using the full model with contrast statements. We compared the effects of cheatgrass control on seedling establishment and cheatgrass and existing plant cover (Table 3). Contrast statements were also used to compare the effects of seeding on cheatgrass reestablishment and existing plant cover ( $\mathrm{Ta}$ ble 3).

Because of technical difficulties, cover and richness data for August 2005 were missing for nine plots (all treatments except 
Table 3. Treatment comparisons of glyphosate and seeding on cheatgrass control and specific restoration targets using contrast statements. Contrasts were analyzed using the appropriate full statistical model (seedling or cover data). Seed mixture treatments following glyphosate control are abbreviated as follows: no seed control (NSC), early succession species seeded year one (ES), early and late succession species seeded year one (ELS), late succession species seeded year one (LS), early succession species seeded year one + late succession species seeded year two (ELS2), no seed year one + late succession species seeded year two (LS2). A no-glyphosate control is included in these comparisons that received the same application as ELS, but cheatgrass was not controlled with glyphosate (NGC). Sampling time 2003 is the pretreatment baseline and was included to check for pretreatment differences; 2005 is the second growing season after the first seeding treatment and averages together the July and August sampling dates. Treatment abbreviations separated by a "p" are averaged together in the analysis. ${ }^{1}$

\begin{tabular}{|c|c|c|c|c|c|c|}
\hline Contrast question & Contrast response & Response variable & Treatment comparisons & Time & df & $\mathrm{F}$ \\
\hline $\begin{array}{l}\text { Did cheatgrass removal improve late } \\
\text { succession seedling establishment? }\end{array}$ & No & $\begin{array}{l}\text { Late succession } \\
\text { seedlings }\end{array}$ & ELS, NGC & NA & 1,40 & 0.84 \\
\hline $\begin{array}{l}\text { Did cheatgrass removal improve early } \\
\text { succession seedling establishment? }\end{array}$ & No & $\begin{array}{l}\text { Early succession } \\
\text { seedlings }\end{array}$ & ELS, NGC & NA & 1,62 & 3.07 \\
\hline $\begin{array}{l}\text { Did cheatgrass removal decrease } \\
\text { cheatgrass cover in the second year after } \\
\text { glyphosate application? }\end{array}$ & Yes & Cheatgrass cover & ELS, NGC & $\begin{array}{l}2003 \\
2005\end{array}$ & $\begin{array}{l}1,296 \\
1,296\end{array}$ & $\begin{array}{l}1.09 \\
6.48^{\star \star}\end{array}$ \\
\hline $\begin{array}{l}\text { Did cheatgrass removal increase perennial } \\
\text { plant growth? }\end{array}$ & No & Perennial plant cover & ELS, NGC & $\begin{array}{l}2003 \\
2005\end{array}$ & $\begin{array}{l}1,297 \\
1,297\end{array}$ & $\begin{array}{l}0.32 \\
0.32\end{array}$ \\
\hline $\begin{array}{l}\text { Did late succession seed mixtures increase } \\
\text { native perennial cover compared to } \\
\text { nonseeded plots? }\end{array}$ & No & Perennial plant cover & LS/LS2/ELS/ELS2, NSC & $\begin{array}{l}2003 \\
2005\end{array}$ & $\begin{array}{l}1,297 \\
1,297\end{array}$ & $\begin{array}{l}0.51 \\
0.07\end{array}$ \\
\hline $\begin{array}{l}\text { Did early succession seed mixtures } \\
\text { increase native annual cover compared to } \\
\text { nonseeded plots? }\end{array}$ & Yes* $^{*}$ & Native annual cover & ES/ELS/ELS2, NSC & $\begin{array}{l}2003 \\
2005\end{array}$ & $\begin{array}{l}1,297 \\
1,297\end{array}$ & $\begin{array}{l}0.94 \\
3.27^{\star}\end{array}$ \\
\hline $\begin{array}{l}\text { Did seeding treatments in general reduce } \\
\text { cheatgrass regrowth cover compared to } \\
\text { not seeding? }\end{array}$ & No & Cheatgrass cover & LS/LS2/ES/ELS/ELS2, NSC & $\begin{array}{l}2003 \\
2005\end{array}$ & $\begin{array}{l}1,296 \\
1,296\end{array}$ & $\begin{array}{l}0.01 \\
0.71\end{array}$ \\
\hline $\begin{array}{l}\text { Did seeding treatments in general reduce } \\
\text { nonnative species cover compared to not } \\
\text { seeding? }\end{array}$ & Yes* $^{*}$ & Nonnative species cover & LS/LS2/ES/ELS/ELS2, NSC & $\begin{array}{l}2003 \\
2005\end{array}$ & $\begin{array}{l}1,297 \\
1,297\end{array}$ & $\begin{array}{l}0.96 \\
3.46^{\star}\end{array}$ \\
\hline
\end{tabular}

${ }^{1}$ Significance levels: ${ }^{*}$ at $\alpha=0.10 ;{ }^{* *}$ at $\alpha=0.01$.

ELS2 from one block and all single-year treatments from another block).

\section{RESULTS}

\section{Soil Training Greenhouse Experiment}

AMF Colonization and Fitness. The mean number of spores was highest in the A. frigida-trained soils, and no differences were detected among cheatgrass, C. viscidiflorus, or E. elymoides-trained soils (Fig. 1A). Spore numbers were higher in pots inoculated with C. viscidiflorus soil compared with those inoculated with A. frigida soil, when averaged across trainer plants (Fig. 1A). Both the overall soil inoculum and trainer species factors were significant at the $\alpha=0.05$ level (Inoculum $\quad \mathrm{F}_{1,27}=4.04, \quad P=0.05 ; \quad$ Trainer $\quad \mathrm{F}_{3,27}=7.21$, $P=0.001)$.

Percentage of A. frigida and C. viscidiflorus indicator root length colonized by AMF was greater in A. frigida than in C. viscidiflorus-trained soils. Cheatgrass did not have a differential effect on percentage of root colonization compared with the other species (Fig. 1B). In this analysis both the overall soil inoculum and trainer species factors were significant at the $\alpha=0.01$ level (Indicator $F_{\text {df } 1,27}=19.72, P=0.0001$, Trainer $\left.\mathrm{F}_{\mathrm{df}} 3,27=4.16, P=0.01\right)$. Viewing the spore and root colonization data together, AMF associated with A. frigida trainer plants sporulated more profusely than the other plant species. Because spores are reproductive bodies, their elevated numbers likely translated directly into the higher rate of indicator plant root colonization in the A. frigida-trained soils. When averaged across soil-training treatments, AMF colonized a greater proportion of the roots in the indicator species $C$. viscidiflorus than in A. frigida (Fig. 1B).

Indicator plant growth was greater with AMF inoculation than without (Fig. 2), demonstrating a positive response to AMF for both indicator plant species. Above-ground biomass differences were detected among soil-training treatments for AMF-colonized A. frigida and noncolonized C. viscidiflorus indicator plants at the $\alpha=0.10$ level (Fig. 2). Within the AMFinoculated treatments, these results indicate that cheatgrass soil training did not affect native plant growth differently from native plant soil training (Fig. 2). In the absence of AMF, growth of C. viscidiflorus was reduced with cheatgrass-trained soil compared to its own trained soil. This trend was reversed in the AMF treatments in which cheatgrass-trained soils appear to slightly improve C. viscidiflorus growth, although this result is not significant (Fig. 2).

\section{Seeding and Glyphosate Field Experiment}

No evidence was found to support the idea that cheatgrassassociated soils inhibit seedling establishment or native plant 
(A)

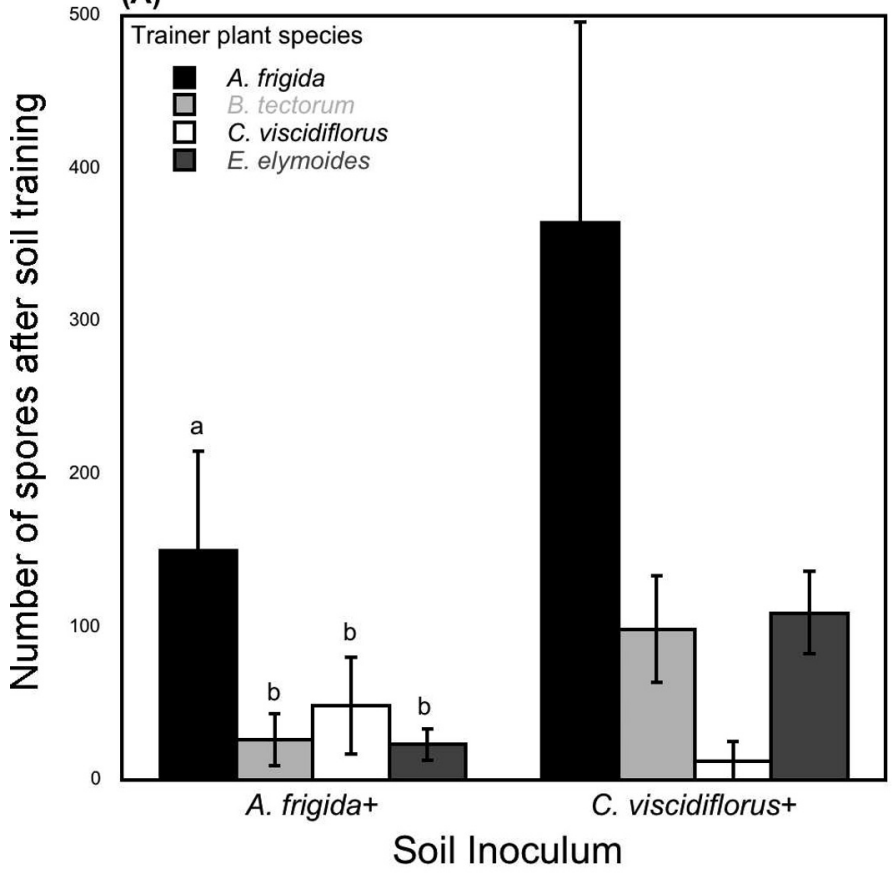

(B)

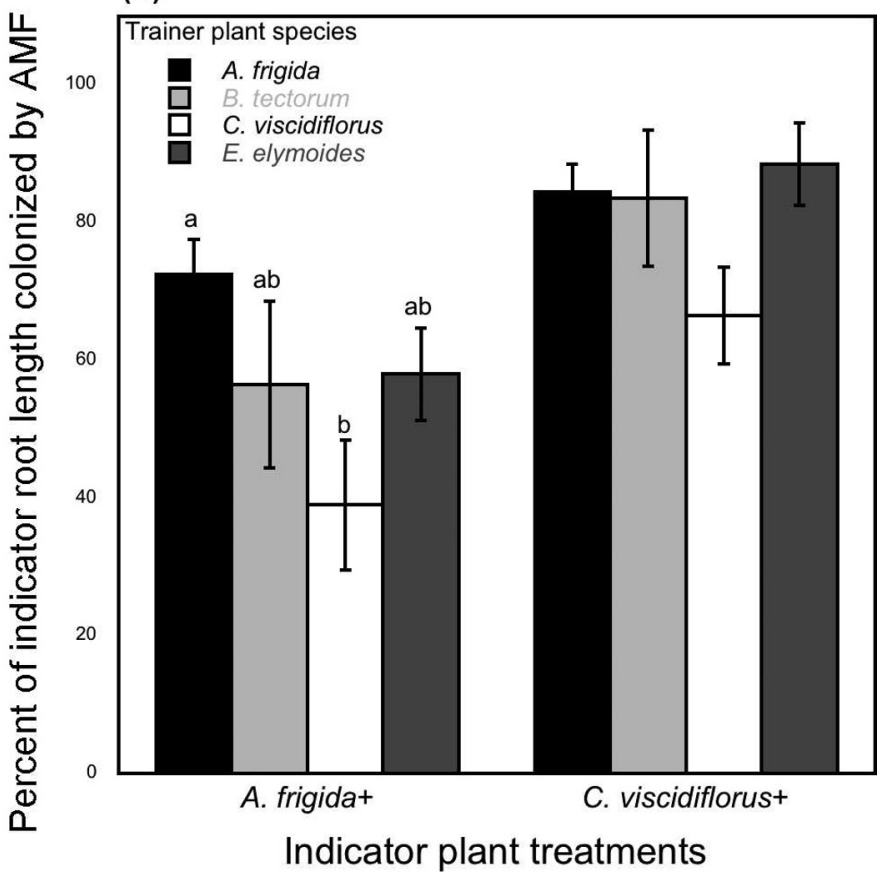

Figure 1. A, Mean number of spores per $50 \mathrm{~mL}$ soil extracted after soil training. B, Percentage of indicator plant roots colonized by arbuscular mycorrhizal fungi (AMF). Error bars represent one standard error of the mean. The symbol + denotes AMF inoculation treatment. Different letters indicate differences between trainer plant treatments and are placed only once in the figures to indicate that these are averaged across soil inoculum or indicator plant treatment for A and B, respectively, using Tukey's HSD test $(\alpha=0.05)$.

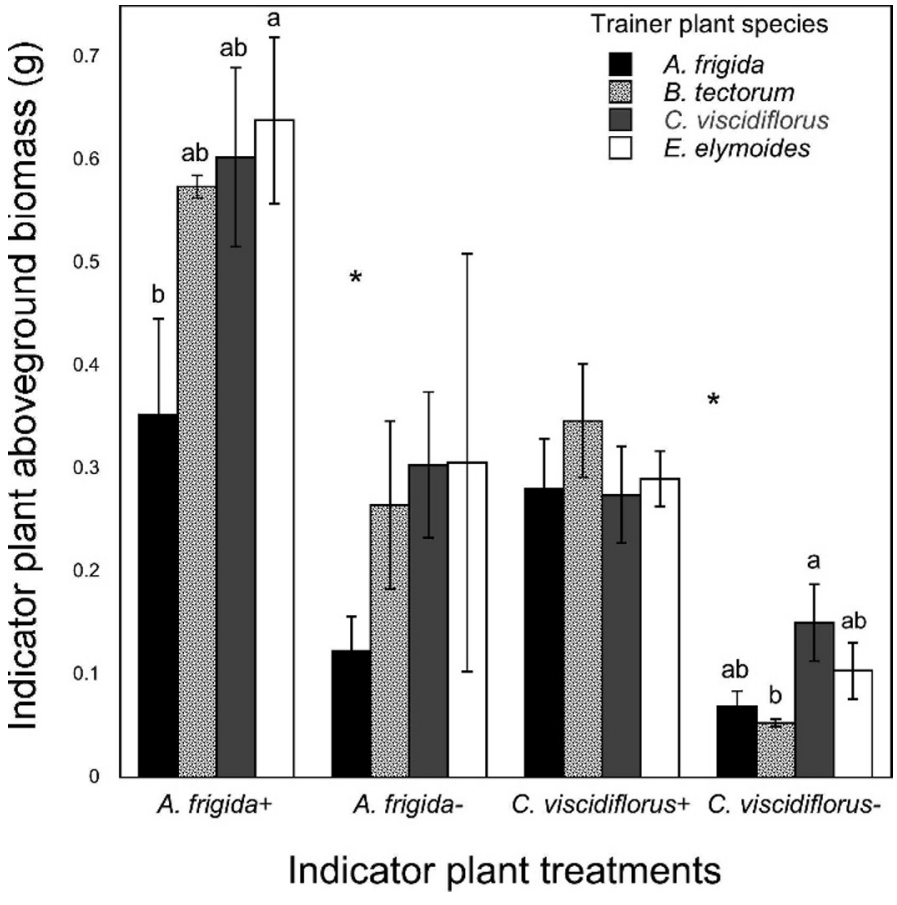

Figure 2. Above-ground biomass of indicator plants as influenced by trainer plant species and arbuscular mycorrhizal fungi (AMF) inoculation. The symbols + and - denote AMF inoculation or sterile soil with filtrate treatment, respectively. Asterisks indicate a significant difference using a Student's $t$ test between AMF-inoculated and -uninoculated plants $(P<0.0001)$. Different letters indicate differences between trainer plant treatments within each indicator treatment using Tukey's HSD test $(\alpha=0.10)$. The absence of letters indicates no difference among trainer plant treatments. Error bars represent one standard error of the mean. growth in this system. Total seedling establishment averaged $14.02 \pm 1.7 \mathrm{~m}^{2}$ across all treatments. Seeding treatments were more effective for establishing early succession seedlings compared to late succession seedling establishment. Seed mixtures slightly increased late succession seedling establishment, over natural seed bank and seed rain establishment. In the 1-yr treatments late succession species established better with seeding (ELS and LS treatments) compared with no seed (NSC), although establishment of these species did not differ between being seeded in the late succession treatment (LS) and not being seeded in the early succession treatment $\left(\mathrm{ES} ; \mathrm{F}_{\mathrm{df}}{ }_{3,29}=3.27\right.$, $P=0.04$; Fig. $3 \mathrm{~A})$. In the 2 -yr treatments, late succession seedlings established no better with seeding treatments (LS2, ELS2) than with ambient seed rain (NSC; $\mathrm{F}_{\mathrm{df}} 2,20=2.70$, $P=0.09$; Fig. 3B), but in these treatments the late succession species only had 1 yr to establish (2005), and they experienced more cheatgrass competition in this year than the 1 -yr treatments did in 2004, the first year when glyphosate was applied (Fig. 4).

Overall, early succession species seedling establishment was higher when seeded (ES, ELS, ELS2 treatments) compared to natural seed rain (NSC, LS, LS2 treatments; Fig. 5). Chenopodium leptophyllum established especially well from seed (Fig. 5).

All functional groups increased in cover and richness with time, indicating that there were few, if any, inhibitory factors to growth (Table 2). Perennial native plant cover increased fourfold from $8.05 \pm 1.09 \%$ to $33.01 \pm 3.2 \%$ over the $3 \mathrm{yr}$. Overall, seed treatments did not affect existing plant cover except for perennial forbs, which had pretreatment differences (Table 2). Treatment by time differences in perennial grass richness (Table 2) can be attributed to seasonal differences in peak standing biomass among grass species. 
(A)

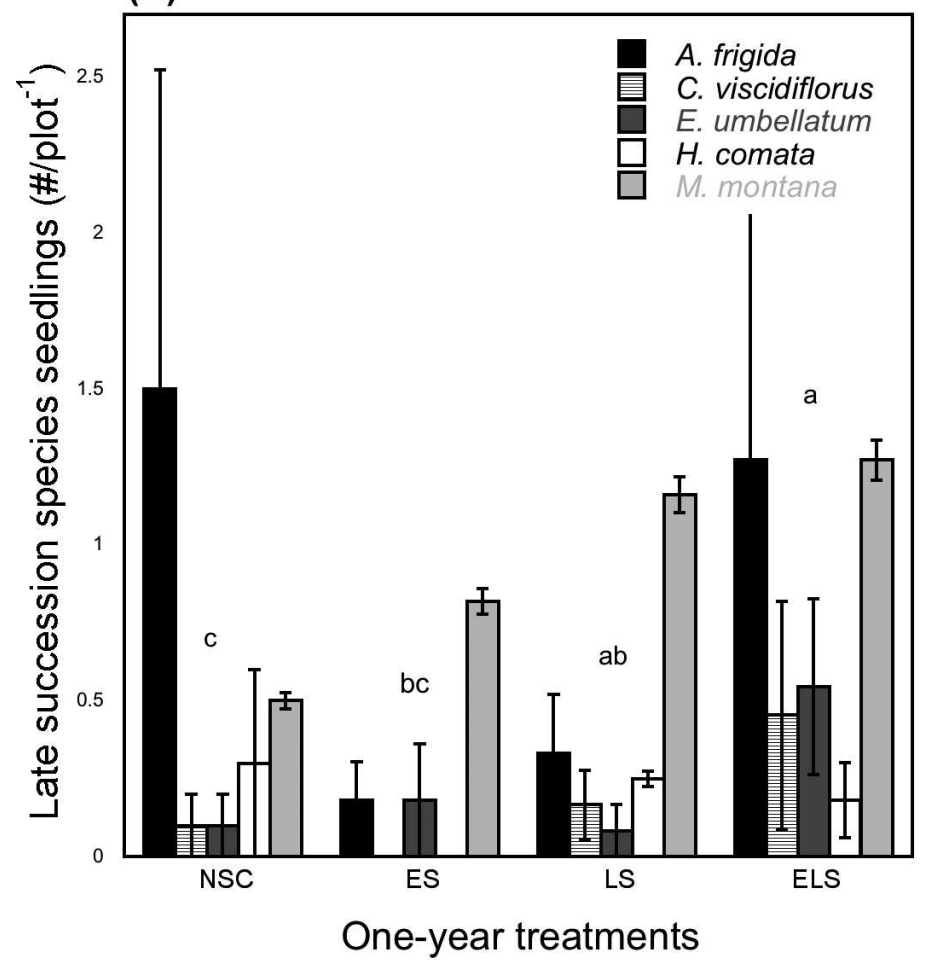

(B)

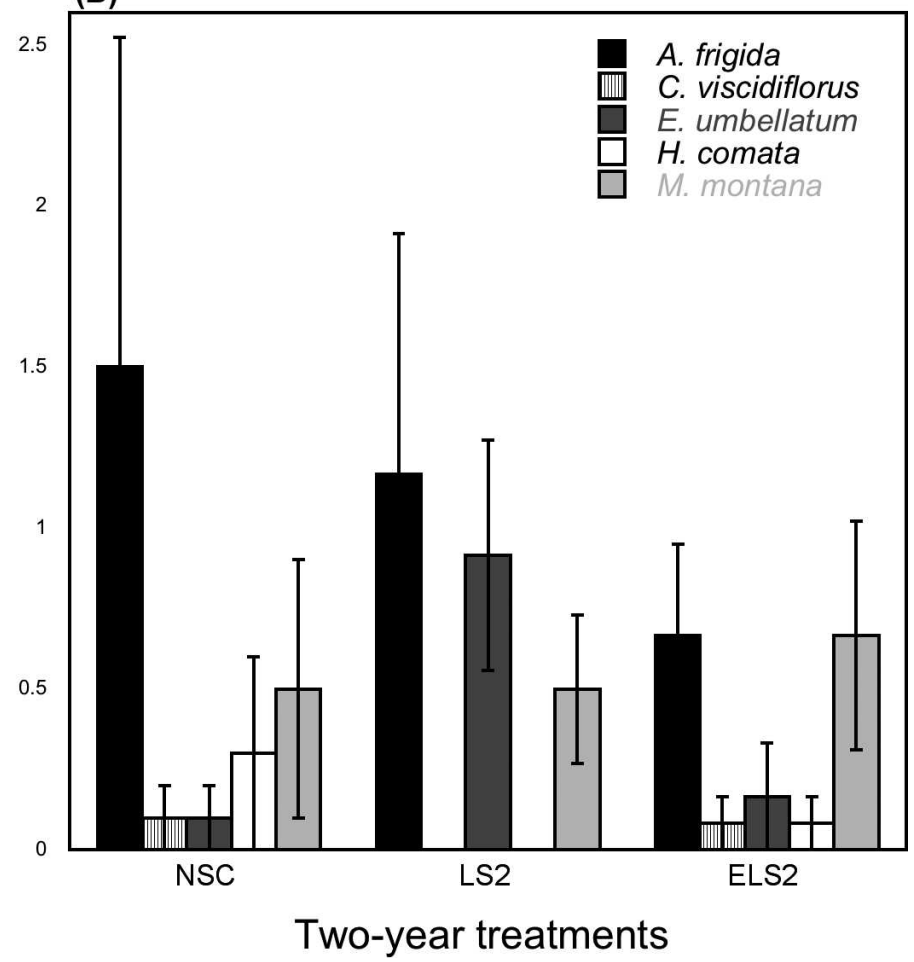

Figure 3. Late succession species establishment for A, 1-yr treatments and B, 2-yr treatments. Error bars represent one standard error of the mean. Different letters indicate differences among seed treatments using F-protected differences of least squared means $(\alpha=0.05)$. First-year seed mixture treatments are as follows: no seed control (NSC), early succession species (ES), late succession species (LS), early and late succession species (ELS); second-year seed mixture treatments are as follows: late succession species planted year two (LS2), no seed control (NSC), early succession species planted year one + late succession species planted year two (ELS2). Number of seeds reflects the mean found per $0.5-\mathrm{m}^{2}$ plot.

Cheatgrass control was fairly short lived. Glyphosate reduced cheatgrass cover by $10 \%$ in the glyphosate-treated plots compared to the nontreated plots in the second season after glyphosate treatment (Table 3; early and late succession seed with glyphosate mean $53.77 \pm 3.70[n=22]$, nonglyphosate control mean $63.95 \pm 4.54[n=22])$. This temporary release from cheatgrass did not improve early or late succession seedling establishment (Table 3) or foster perennial plant growth (Table 3). Likewise, none of the seeding mixtures effectively prevented cheatgrass regrowth (Table 3 ).

When considering specific restoration objectives, seed mixtures did not increase existing native perennial plant cover
(Table 3 ). Seed treatments with early succession species slightly increased the cover of native annual forbs and all seeding treatments averaged together slightly repressed nonnative growth compared with no seeding (Table 3).

\section{DISCUSSION}

Cheatgrass invasion does not appear to be facilitated by soil community interactions at this high elevation site. The presence of cheatgrass has been shown to reduce AMF propagules in the soil or change AMF community structure (Al-Qarawi 2002;

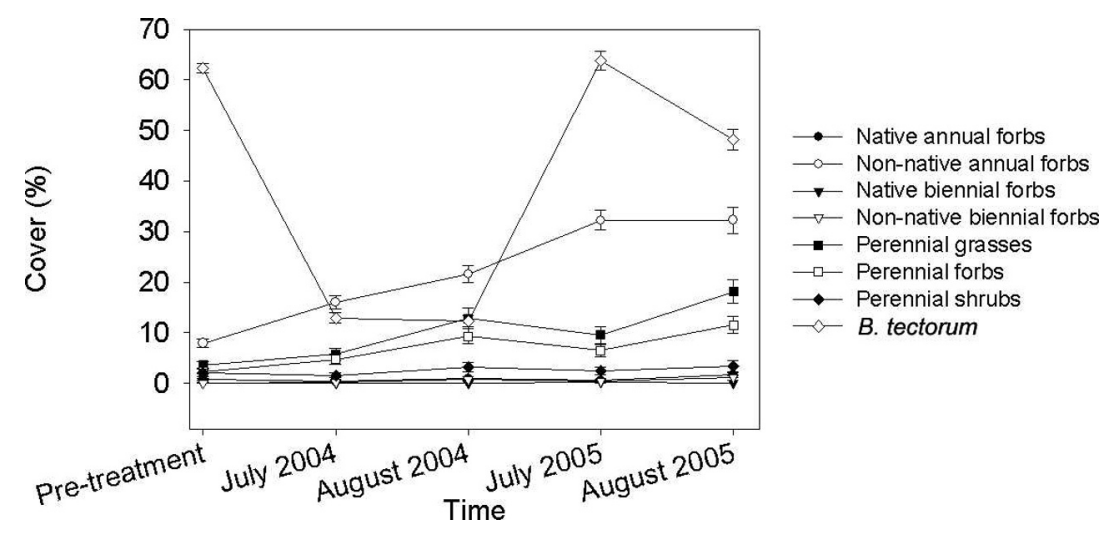

Figure 4. Change in mean plant cover over time by functional group. Mean plant cover is an average of the six seeding treatments treated with glyphosate in April 2004. 


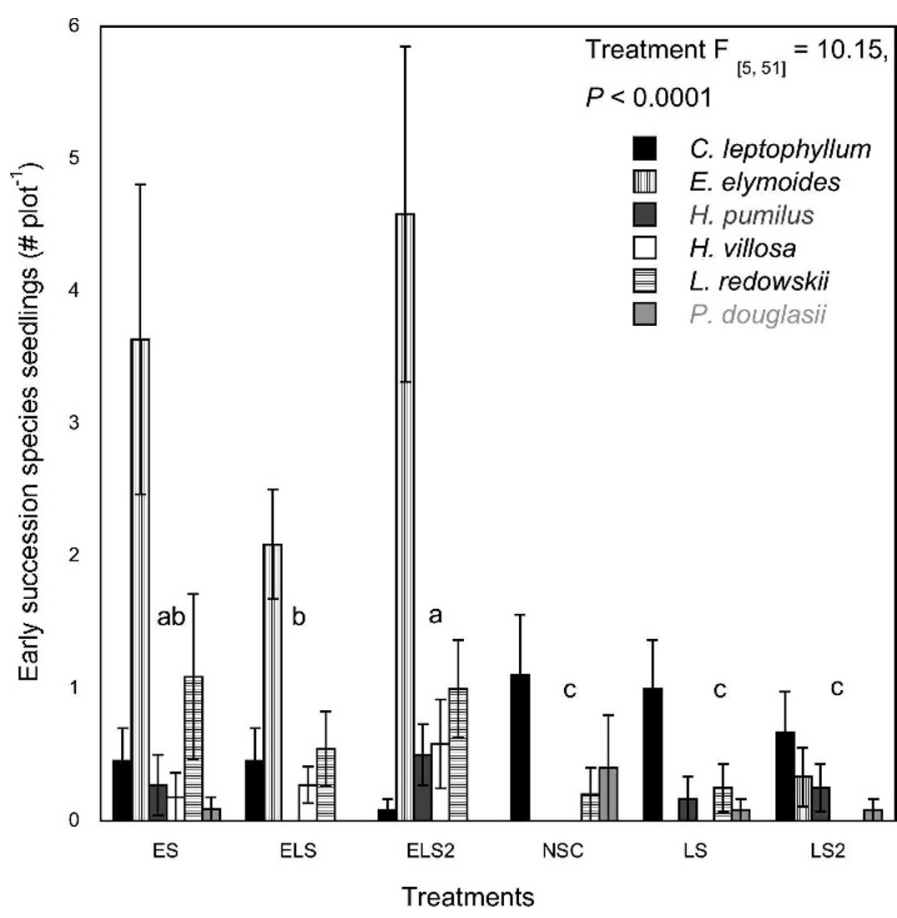

Figure 5. Early succession species establishment for all seed treatments. Error bars represent one standard error of the mean. Different letters indicate differences among seed treatments using F-protected differences of least squared means $(\alpha=0.05)$. Seed mixture treatments are as follows: early succession species seeded year one (ES), early and late succession species seeded year one (ELS), early succession species seeded year one + late succession species seeded year two (ELS2), no seed control (NSC), late succession species seeded year one (LS), no seed year one + late succession species seeded year two (LS2). Number of seeds reflects the mean found per $0.5-\mathrm{m}^{2}$ plot.

Hawkes et al. 2006); therefore we were concerned that these changes would inhibit establishment and growth of native vegetation and lead to cheatgrass monocultures. Despite these reported impacts of cheatgrass on soil communities in some study systems, cheatgrass-influenced soils at our study site do not appear to impair establishment or growth of native plant species relative to the same native plant species grown in native-plant-influenced soils in the greenhouse. If cheatgrass had inhibitory effects on AMF, then cheatgrass should have decreased AMF sporulation, reduced the colonization of AMF in native perennial plants, or reduced the growth of plants growing in association with cheatgrass-trained soils. Our greenhouse study did not detect such changes, and these findings are confirmed by results from the field.

We found that the capacity for native plant species recruitment, establishment, and growth was still present, if not intact at our field site. If soils had been negatively affected, we expected to have seen poor seedling establishment and plant growth of native species without additional inputs in the field experiment. AMF can be important in the recruitment of seedlings in existing vegetation (van der Heijden 2004). Seedling establishment on our field site suggests that sufficient soil microbes required for establishment were still present. In fact, it appeared that seeding late succession species gave a slight edge to establishment compared to not seeding, but these same plants also established favorably with the ambient seed rain. Seeding early succession species improved establishment compared with natural seed rain, and, moreover, because of their fast growth, these changes were reflected in an increased cover of native annual forbs (at the $\alpha=0.10$ level). The existing plant community increased over the duration of this study across all functional groups. Thus, there did not appear to be significant barriers to natural recruitment or the growth of existing native vegetation.

Although we cannot assert that AMF or other soil attributes have not been affected by cheatgrass in the field, nor can we claim to know if recruitment would be higher had cheatgrass not previously invaded this site, together our results show that native vegetation persistence was not threatened by cheatgrassmediated changes to the soil community under the conditions at this site. It remains possible that cheatgrass may make changes to the soil community or nutrient availability in ways that benefit its own persistence, but that do not inhibit native plant communities. In fact, changes in soil nutrient availability associated with cheatgrass invasion, particularly $\mathrm{N}, \mathrm{P}$, and $\mathrm{Mn}$, have been reported (Evans et al. 2001; Booth et al. 2003; Miller et al. 2006; Rimer and Evans 2006; Sperry et al. 2006).

The glyphosate treatments were intended to control cheatgrass so that native plant establishment and growth could be tested in isolation from cheatgrass competition. The suppression of cheatgrass cover to $<5 \%$ with glyphosate effectively removed competition in the first year, and by the second year cheatgrass was $10 \%$ less abundant in the ELS glyphosate plots compared with the control treatment (NGC). This absence of competition did not improve establishment or growth of perennial species compared with no-glyphosate application, although perhaps a second year of suppression may have changed this outcome. The problem of controlling cheatgrass at this site has not been solved. We used glyphosate because of National Park Service regulations; perhaps herbicides with a proven efficacy on cheatgrass control such as imazapic could be applied at similar sites, although nontarget effects are still of concern.

Comparisons of the seeding treatments also yield important information for restoration efforts. It appears that late succession and early succession plant species can be seeded together or separately with equal establishment success; therefore the choice of seeding together or separately can be made depending on other factors, such as seed availability and restoration objectives. Planting early succession seeds resulted in a greater difference between seeding and natural seed rain than did late succession seeds. Therefore, if the objective is to increase vegetation quickly, early succession seed mixes appear more promising. Late succession plants already on the site will likely seed themselves over time. None of the seeding treatments reduced cheatgrass regrowth, but seeding in general did have a slight suppressive effect on the growth of other nonnative plants (at the $\alpha=0.10$ level).

The success of both seeding and seed rain in seedling establishment and the lack of an inhibitory effect of cheatgrasstrained soil suggests that cheatgrass invasion is not being facilitated by belowground soil interactions in this study system. It gives hope that in the presence of sufficient native vegetation intensive restoration efforts may not be required to reestablish native plant dominance. At this study site and perhaps others like it, a return to the natural state appears possible if the invasive plant can be controlled. 


\section{ACKNOWLEDGMENTS}

We thank M. McMillan and R. Advani for lab assistance and V. Beauchamp for guidance in spore isolation methods. Comments from three anonymous reviewers improved the clarity and quality of the manuscript.

\section{LITERATURE CITED}

AL-QARaWI, A. A. 2002. Relationships among nitrogen availability, vesiculararbuscular mycorrhizae, and Bromus tectorum in disturbed sites in Colorado [dissertation]. Fort Collins, CO, USA: Colorado State University. 100 p.

Allen, E. B. 1988. Some trajectories of succession in Wyoming sagebrush grassland: implications for restoration. In: E. B. Allen [ED.]. The reconstruction of disturbed arid lands: an ecological approach. Boulder, CO, USA: Westview Press. p. 89-112.

Allen, E. B. 1995. Mycorrhizal limits to rangeland restoration: soil phosphorus and fungal species composition. In: N. E. West [ED.]. International Proceedings of the V International Rangeland Congress; 23-28 July 1995; Salt Lake City, UT, USA. Denver, C0, USA: Society for Range Management. p. 57-61.

Association of Official Seed Analysts. 2003. Rules for testing seeds. Las Cruces, NM, USA: Association of Official Seed Analysts. $168 \mathrm{p}$.

Belnap, J., And S. L. Philips. 2001. Soil biota in an ungrazed grassland: response to annual grass (Bromus tectorum) invasion. Ecological Applications 11:1261-1275.

BEVER, J. D. 2002. Negative feedback within a mutualism: host-specific growth of mycorrhizal fungi reduces plant benefit. Proceedings of the Royal Society of London 269:2595-2601.

Bever, J. D., J. B. Morton, J. Antonovics, and P. A. Schultz. 1996. Host-dependent sporulation and species diversity of arbuscular mycorrhizal fungi in a mown grassland. Journal of Ecology 84:71-82.

Bever, J. D., A. Pringle, and P. A. Schultz. 2002. Dynamics within the plantarbuscular mycorrhizal fungal mutualism: testing the nature of community feedback. In: M. G. A. van der Heijden and I. R. Sanders [Eds.]. Mycorrhizal ecology. Berlin, Germany: Springer. p. 268-292.

Booth, M. S., J. M. Stark, and M. M. Caldwell. 2003. Inorganic N turnover and availability in annual- and perennial-dominated soils in a northern Utah shrubsteppe ecosystem. Biogeochemistry 66:311-330.

Dakheel, A. J., S. R. Radosevich, and M. G. Barbour. 1993. Effect of nitrogen and phosphorus on growth and interference between Bromus-tectorum and Taeniatherum-asperum. Weed Research 33:415-422.

Daniels, B. A., AND H. D. Skipper. 1982. Methods for the recovery and quantitative estimation of propagules from soil. In: N. C. Schenck [ED.]. Methods and principles of mycorrhizal research. St. Paul, MN, USA: American Phytopathological Society. p. 29-35.

Diтomaso, J. M. 2000. Invasive weeds in rangelands: species, impacts, and management. Weed Science 48:255-265.

Evans, R. D., R. Rimer, L. Sperry, and J. Belnap. 2001. Exotic plant invasion alters nitrogen dynamics in an arid grassland. Ecological Applications 11:13011310.

Fulbright, T. E., E. F. Redente, and N. E. Hargis. 1982. Growing Colorado plants from seed: a state of the art. Washington, DC, USA: US Department of the Interior, Fish and Wildlife Service. Report FWS/OBS-82/29. 113 p.

Gemma, J. N., R. E. Koske, and M. Habte. 2002. Mycorrhizal dependency of some endemic and endangered Hawaiian plant species. American Journal of Botany 89:337-345.

GoodwIN, J. 1992. The role of mycorrhizal fungi in competitive interactions among native bunchgrasses and alien weeds: a review and synthesis. Northwest Science 66:251-260.

Hawkes, C. V., J. Belnap, C. D'Antonio, and M. K. Firestone. 2006. Arbuscular mycorrhizal assemblages in native plant roots change in the presence of invasive exotic grasses. Plant and Soil 281:369-380.

Hulbert, L. C. 1955. Ecological studies of Bromus tectorum and other annual bromegrasses. Ecological Monographs 25:181-213.
Humphrey, L. D., and E. W. Schupp. 2001. Seed banks of Bromus tectorumdominated communities in the Great Basin. Western North American Naturalist 61:85-92.

International Culture Collection of (Vesicular) Arbuscular Mycorrhizal Fungi. 2005. Plant and mycorrhiza root lengths. Available at: http://invam.caf.wvu.edu/ methods/mycorrhizae/rootlengths.htm. Accessed July 2005.

Johnson, N. C., D. L. Rowland, L. Corkidi, L. M. Egerton-Warburton, and E. B. Allen. 2003. Nitrogen enrichment alters mycorrhizal allocation at five mesic to semiarid grasslands. Ecology 84:1895-1908.

Kay, B. L., and R. A. Evans. 1965. Effects of fertilization on a mixed stand of cheatgrass and intermediate wheatgrass. Journal of Range Management 18:7-11.

Klemmedson, J. O. 1964. Cheatgrass (Bromus tectorum L. C.). Botanical Review 30:226-262.

KnapP, P. A. 1996. Cheatgrass (Bromus tectorum L) dominance in the Great Basin Desert-history, persistence, and influences to human activities. Global Environmental Change—Human and Policy Dimensions 6:37-52.

Kormanik, P. P., W. C. Bryan, and R. C. Schultz. 1980. Procedures and equipment for staining large numbers of plant root samples for endomycorrhizal assay. Canadian Journal of Microbiology 26:536-538.

Koske, R. E., AND J. N. Gemma. 1989. A modified procedure for staining roots to detect VA mycorrhizas. Mycological Research 92:486-490.

Lauenroth, W. K., J. L. Dodd, and P. L. Sims. 1978. The effects of water- and nitrogen-induced stresses on plant community structure in a semiarid grassland. Oecologia 36:211-222.

McGonigle, T. P., M. H. Miller, D. G. Evans, and G. L. Fairchild. 1990. A new method which gives an objective measure of colonization of roots by vesicular-arbuscular mycorrhizal fungi. New Phytologist 115:495-501.

Miller, M. E., J. Belnap, S. W. Beatty, and R. L. Reynolds. 2006. Performance of Bromus tectorum $L$. in relation to soil properties, water additions, and chemical amendments in calcareous soils of southeastern Utah, USA. Plant and Soil 288:1-18.

Paschke, M. W., T. McLendon, and E. F. Redente. 2000. Nitrogen availability and oldfield succession in a shortgrass steppe. Ecosystems 3:144-158.

Redente, E. F., P. R. Ogle, and N. E. Hargis. 1982. Growing Colorado plants from seed: a state of the art. Vol. III: Forbs. Washington, DC, USA: US Department of the Interior, Fish and Wildlife Service. Report FWS/OBS-82-30. $141 \mathrm{p}$.

Rimer, R. L., And R. D. Evans. 2006. Invasion of downy brome (Bromus tectorum L.) causes rapid changes in the nitrogen cycle. American Midland Naturalist 156:252-258.

Rowe, H. I., C. S. Brown, and V. P. Claassen. 2007. Comparisons of mycorrhizal responsiveness with field soil and commercial inoculum for six native montane species and Bromus tectorum. Restoration Ecology 15:44-52.

SAS [computer program]. 2002-2003. Version 9. Cary, NC, USA: SAS Institute, Inc.

Smith, S. E., and D. J. Read. 1997. Mycorrhizal symbiosis. San Diego, CA, USA: Academic Press.

Sperry, L. J., J. Belnap, and R. D. Evans. 2006. Bromus tectorum invasion alters nitrogen dynamics in an undisturbed arid grassland ecosystem. Ecology 87:603-615.

VAN deR HeIJDEN, M. G. A. 2004. Arbuscular mycorrhizal fungi as support systems for seedling establishment in grassland. Ecology Letters 7:293-303.

Vierheilig, H., A. P. Coughlan, U. Wys, and Y. Piche. 1998. Ink and vinegar, a simple staining technique for arbuscular-mycorrhizal fungi. Applied and Environmental Microbiology 64:5004-5007.

Western Regional Climate Center. 2006. Historical climate information. Available at: http://www.wrcc.dri.edu/. Accessed 14 March 2006.

Whitson, T. D., AND D. W. Koch. 1998. Control of downy brome (Bromus tectorum) with herbicides and perennial grass competition. Weed Technology 12:391-396.

Wilson, G. W. T., and D. C. Hartnetr. 1998. Interspecific variation in plant responses to mycorrhizal colonization in tallgrass prairie. American Journal of Botany 85:1732-1738.

Wolfe, B. E., And J. N. KLiRonomos. 2005. Breaking new ground: soil communities and exotic plant invasion. BioScience 55:477-487. 